\title{
EFFECT OF NANOMETRIC NITROGEN AND MICRO ELEMENTS FERTILIZERS ON YIELD AND ITS COMPONENT OF CANOLA (Brassica napus, L.)
}

\author{
Alwakel, E. Sh. ; M.A. Rizk ; M.H. Fayed and N.E. Darwish
}

Department of Agronomy, Faculty of Agriculture, Al-Azhar University.

\section{ABSTRACT}

Two field experiments were carried out during 2017/2018 and 2018/2019 seasons at Al -Hussein Society of Reclaiming and Cultivating Land, $64 \mathrm{~km}$ Cairo Alexandria desert road, Giza Governorate, Egypt, to study the effect of nitrogen with nano metric fertilizer rates and some micro elements on Productivity and quality of canola c.v. Serw4. The experimental design used was a split plot design with three replications. Each replicate included 20 concentrates which were the combinations between five nitrogen fertilizer rates, i.e., $10 \mathrm{~kg} \mathrm{~N}$ (mineral) $+20 \%$ from recommended nitrogen as nano. $\mathrm{N} /$ fed., $20 \mathrm{~kg}$ (mineral) $+20 \%$ nano, $30 \mathrm{~kg} \mathrm{~N}+20 \%$ nano, $40 \mathrm{~kg} \mathrm{~N}$ (mineral) $+20 \%$ nano. N, $50 \mathrm{~kg} \mathrm{~N}$ (mineral) $+20 \%$ nano. $\mathrm{N}$. were allocated in the main plots, and four micro elements rates used as nano metric fertilizers, Control (sprayed plants with recommended of Iron+ manganese), spraying plants with $\mathrm{Fe}+\mathrm{Mn}$ at concentrations 100, 200, and $300 \mathrm{ppm}$ concentrates, while micro elements were distributed randomly in the sub plots. while $50 \mathrm{kgN}+20 \%$ nano/fed rate gave the maxmum for plant height and number of branches/plant in the two seasons.

The obtained results showed that nitrogen fertilizer rates significantly affected yield of canola and growth characters in both seasons. Application nitrogen fertilizer with rate $(40 \mathrm{~kg} \mathrm{~N}+20 \%$ nano. $\mathrm{N} / \mathrm{fed})$ gave the highest seed yield and 1000seed weight. The obtained results indicated that spraying canola plants with $\mathrm{Fe}+\mathrm{Mn}$ at concentrations $300 \mathrm{ppm}$ increased yield and growth characters in both seasons as compared with the control. However, the obtained results indicate that to obtain higher characters for canola, it is recommended that application nitrogen fertilizer with rate $40 \mathrm{~kg} \mathrm{~N}+20 \%$ nano. $\mathrm{N} /$ fed and applying spraying plants with $\mathrm{Fe}+\mathrm{Mn}$ at concentrations 300 ppm under drip-irrigated and experiment soil condition.

\section{INTRODUCTION}

Oil Crops are important strategic crops in Egypt or in countries around the world, it considered a major source of food in terms of human consumed in different ways in the diet is also important food commodities which the food gap, where up Self-sufficiency ratio of crop oils in the range of $10 \%$ from 13\% despite the multiplicity of oil crops that can be grown in Egypt, but the limited space of this crop does not exceed 3\% of the cropped area in Egypt, The problem despite an increase in domestic production, but there is still a gap between the production and consumption of oil crops, which form 
a burden on the Egyptian trade balance so it is necessary to increase the local production of crop oils, by expanding the cultivation of oil crops to produce oilseeds by increasing the cultivated areas with new oil crops do not compete with the main crops, which can be extracted from its seeds to meet the increasing consumption and who leads in fluctuation its domestic prices.

Canola (Brassica napus L.) belongs to Brassicaceae group of oilseed crops and considered one of the prime sources for edible vegetable oil for human consumption due to its higher quality associated with a lower level of saturated fat (40-45\%) and protein (36-40\%) in the seed (Alberta Agriculture, 1984). Currently, it cultivated on an area of 36 million hectares annually with a total production of 72 million tons worldwide (FAOSTAT, 2014).Europe, China and Canada are leading producers of rapeseed with higher area under cultivations and production (Commodity Research Bureau, 2005). Its seed is enriched with $40 \%$ oil content and meal have 35$40 \%$ crude protein. Currently canola oil is considered as acceptable alternative to soya bean oil (Muhammad, et al., 2007). Canola is tolerant to moderate to extreme environmental conditions and can be successfully grown under arid land conditions (Qaderi et al., 2012). To ameliorate this environment stress plant need some support from external sources that may be suitable planting date which favors plant to timely complete its life cycle or nutrients adjustment for better growth and performance (Khaliq et al., 2013).

Nitrogen $(\mathrm{N})$ is an essential nutrient for plant growth and is a key limiting factor in agro-ecosystems. Nitrogen is a constituent of amino acids, which are required to synthesize proteins and other related compounds. It plays a role in almost all plant metabolic processes (Hopkins \& Hunter, 2004). Canola yield and yield components, the number of pods and flowers per plant, the total plant weight and harvest index in some varieties of canola have been found to improve with higher rates of nitrogen (Al-Solaimani $\boldsymbol{e t}$ al., 2015). The highest rates of fertilizer application were found to give significantly higher total dry matter than the lowest rate of fertilizer application (Kumar et al., 1997).

Micro-elements are of high importance in plant nutrition and they should not be neglected although they are needed in minor quantities. Recent research has shown that a small amount of nutrients, especially Fe, and $\mathrm{Mn}$ that have been applied by foliar spraying have significantly increased crop yields (Sarkar, et. al. 2007, Wissuwa, et. al. 2008). Foliar application of microelements is more beneficial than soil application. Since application rates are lesser as compared to soil application, same application could be obtained easily and crop reacts to nutrient application immediately (Zayed, et. al. 2011). Foliar application of micronutrients like iron and manganese significantly increased 1000-kernel weight and seed yield of canola Brassica napus L. (Bahrani and Pourreza 2014). 


\section{MATERIALS AND METHODS}

Two field experiments were carried out at $\mathrm{Al}$-Hussein Society for Reclaiming and Cultivating Land,64 km Cairo Alexandria desert road, Giza Governorate, Egypt, during two successive agricultural winter seasons $2017 \backslash 2018$ and $2018 \backslash 2019$, to study the effect of nitrogen with nano metric fertilizer rates and some micro elements on Productivity and quality of canola c.v. Serw4.

The experiment concentrates were five nitrogen rates $10 \mathrm{~kg} \mathrm{~N}$ (mineral) $+20 \%$ from recommended nitrogen as nano. $\mathrm{N} / \mathrm{fed}, 20 \mathrm{~kg}$ (mineral) $+20 \%$ nano, $30 \mathrm{~kg} \mathrm{~N}($ mineral $)+20 \%$ nano, $40 \mathrm{~kg} \mathrm{~N}$ (mineral) $+20 \%$ nano. $\mathrm{N}$ and $50 \mathrm{~kg} \mathrm{~N}($ mineral $)+20 \%$ nano. $\mathrm{N}$. and four micro elements used as nano metric fertilizers, control (sprayed plants with recommended of Iron + manganese), spraying plants with $\mathrm{Fe}+\mathrm{Mn}$ at concentrations 100, 200, and 300 ppm.

The experiment was laid out in split -plot design with three replications. The main plots were assigned to nitrogen fertilizer rates, sub- plots were assigned to Iron+ manganese fertilizer rates. The area of each sub plot was $10.5 \mathrm{~m}^{2}$ ( $3 \mathrm{~m}$ width $\mathrm{x} 3.5 \mathrm{~m}$ length).

Mechanical and chemical analysis of soil at the experimental site according to standard methods of Page et al. (1982) and Arnold (1986) are presented in Table (1).

Nitrogen fertilizer (mineral) rates studied (ammonium nitrate $33.5 \%$ ) were splitting into three parts, after 15, 30 and 60 days from sowing, Nano nitrogen was added as foliar application on two equal dos after 50 and 65 days from sowing. Nano Iron+ manganese was added as foliar application on two equal dos after 55 and 70 days from sowing.

Table (1). Physical and chemical of the experimental soil, the standard method according to Page et al (1982).

\begin{tabular}{|c|c|c|}
\hline Parameters & 2017/2018 season & 2018/2019 season \\
\hline \multicolumn{3}{|c|}{ Mechanical analysis } \\
\hline Sand \% & 84.72 & 86.54 \\
\hline Silt\% & 10.00 & 8.34 \\
\hline Clay \% & 5.28 & 5.12 \\
\hline Soil textural class & Sandy & Sandy \\
\hline \multicolumn{3}{|c|}{ Chemical analysis } \\
\hline pH soil & 8.5 & 8.2 \\
\hline Ec(mmhos/cm) & 8.3 & 8 \\
\hline Caco3 \% & 2.7 & 2.9 \\
\hline Available N (ppm) & 30 & 32 \\
\hline Available P (ppm) & 10 & 8 \\
\hline Available K (ppm) & 72 & 68 \\
\hline $\mathbf{F e}$ & 0.42 & 0.44 \\
\hline $\mathbf{C u}$ & 0.26 & 0.24 \\
\hline Zn & 0.31 & $\mathbf{0 . 3 3}$ \\
\hline Mn & 0.76 & 0.74 \\
\hline
\end{tabular}


At 15 November in both 2017/2018 and 2018/2019 seasons seeds of canola were hand sown on rows apart $50 \mathrm{~cm}$ and $30 \mathrm{~cm}$ between hills, two plants were leaved in every hill .The preceding crop was sugar beet at two seasons the soil was without sowing (fallow soil) in the summer. The experiment was laid out under drip irrigation system. All other recommended practices for canola production were done according to Egyptian minister of agriculture recommendation. Oil content (\%) in the seeds was determined and petroleum ether as aslovent methods of Association of Official Agriculture Chemists (A.O.A C, 1980).

Data recorded:

1-Growth traits: Ten plants were at random carefully from the middle ridge of each plot in both seasons to measure the following traits.

a) Plant height $(\mathrm{cm})$ was measured from soil surface to the top of stem.

b) Number of branches

2-Yeild components:

1) 1000 seeds weight $(\mathrm{g})$

2) Seeds yield per feddan $(\mathrm{kg})$.

3) Oil content $\%$ in seeds

4) Oil yield per fed (kg).

\section{Statistical Analysis}

All data of different traits for both seasons were collected and subjected to analysis of variance according to Steel $\boldsymbol{e t}$ al. (1997) to sort out significant differences among concentrates. Difference among means was compared using LSD at 5\% probability level.

\section{1- Plant height (cm)}

\section{RESULTS AND DISCUSSION}

Average canola Plant height at harvest time as affected by nitrogen fertilizer rates and spraying with nano $\mathrm{Fe}+\mathrm{Mn}$ as well as their interaction on Plant height at harvest of canola c.v. Serw4 under drip irrigation system in 2017/2018 and 2018/2019 seasons are presented in Tables (2) and (3).

Tables (2) and (3) indicate that canola Plant height was significantly affected by rates of nitrogen fertilizer in both seasons. The results show that the highest nitrogen fertilizer rates gave the Plant height $170.17 \mathrm{~cm}$ and $173.25 \mathrm{~cm}$ in 2017/ 2018 and 2018/ 2019 seasons, respectively. The highest $\mathrm{N}$ level, i.e. $20 \mathrm{~kg} \mathrm{~N}$ nano $+50 \mathrm{~kg} \mathrm{~N}$ mineral/ fed concentrate gave 27.23\%, 20.32, 14.66 and $12.09 \%$ increase in canola Plant height over those of nitrogen fertilizer 10, 20, 30 and $40 \mathrm{~kg}$ $\mathrm{N}$ mineral/ fed concentrates, respectively, in 2017/ 2018 season. The respective values in 201812019 season. These results are in agreement with those of Rathnayaka, et. al. (2018). 
The obtained data (Tables 2 and 3) show that spraying canola plants with $\mathrm{Fe}+\mathrm{Mn}$ significantly affected plant height in both seasons, the highest Plant height values $(123.53$ and $147.54 \mathrm{~cm})$ were obtained with concentrate of $\mathrm{Fe}+\mathrm{Mn} 300$ ppm, in 2017/ 2018 and 2018/ 2019 seasons, respectively, as compared with the other spraying concentrates. In 2017/ 2018 season, this concentrate gave $17.53 \%, 16.73 \%$ and $6.74 \%$ increase in Plant height over those of the control, $\mathrm{Fe}+\mathrm{Mn} 100 \mathrm{ppm}$ and $\mathrm{Fe}+\mathrm{Mn} 200 \mathrm{ppm}$ concentrates, respectively. Results in 2018/ 2019 season followed similar trend. These results are in agreement with those of Sultana, et. al. (2001).

Table 2. Effect of nano metric nitrogen and micro element fertilizer on some characters of canola c.v. Serw4 on 2017/2018 season.

\begin{tabular}{|c|c|c|c|c|c|}
\hline Nitrogen & $\mathbf{F e}+\mathrm{Mn}$ & Plant height & $\begin{array}{c}\text { Number of } \\
\text { branches }\end{array}$ & $\begin{array}{c}\text { 1000seed } \\
\text { weight }\end{array}$ & Seed yield \\
\hline \multirow{5}{*}{$\begin{array}{c}10 \mathrm{~kg} \mathrm{~N} \\
\text { mineral+ } \\
20 \text { nano }\end{array}$} & Control & 115.67 & 6.00 & 1.9 & 887.80 \\
\hline & 100ppm & 114.67 & 5.33 & 2.1 & 1113.20 \\
\hline & 200ppm & 129.67 & 7.67 & 2.37 & 1163.60 \\
\hline & 300ppm & 135.33 & 8.33 & 2.73 & 1232.20 \\
\hline & Mean & 123.84 & 6.83 & 2.28 & 1099.20 \\
\hline \multirow{5}{*}{$\begin{array}{c}20 \mathrm{~kg} \mathrm{~N} \\
\text { mineral+ } \\
20 \text { nano }\end{array}$} & Control & 128.67 & 5.67 & 2. & 1251.80 \\
\hline & 100ppm & 125.67 & 5.00 & 2.23 & 1333.00 \\
\hline & 200ppm & 139.67 & 6.67 & 2.63 & 1401.60 \\
\hline & 300ppm & 148.33 & 7.67 & 2.9 & 1436.60 \\
\hline & Mean & 135.59 & 6.25 & 2.44 & 1355.75 \\
\hline \multirow{5}{*}{$\begin{array}{c}30 \mathrm{~kg} N \\
\text { mineral+ } \\
20 \text { nano }\end{array}$} & Control & 130.33 & 8.67 & 2.23 & 1278.40 \\
\hline & 100ppm & 136.33 & 8.00 & 2.47 & 1254.60 \\
\hline & 200ppm & 148.00 & 10.33 & 2.83 & 1401.60 \\
\hline & 300ppm & 166.67 & 12.33 & 3.10 & 1471.60 \\
\hline & Mean & 145.33 & 9.83 & 2.66 & 1351.55 \\
\hline \multirow{5}{*}{$\begin{array}{c}40 \mathrm{~kg} \mathrm{~N} \\
\text { mineral+ } \\
20 \text { nano }\end{array}$} & Control & 134.67 & 8.77 & 2.23 & 1529.00 \\
\hline & 100ppm & 137.67 & 7.01 & 2.57 & 1445.00 \\
\hline & 200ppm & 158.67 & 12.33 & 3.10 & 1557.00 \\
\hline & 300ppm & 167.33 & 13.33 & 3.37 & 1755.80 \\
\hline & Mean & 149.59 & 10.36 & 2.82 & 1571.7 \\
\hline \multirow{5}{*}{$\begin{array}{c}50 \mathrm{~kg} N \\
\text { mineral+ } \\
20 \text { nano }\end{array}$} & Control & 162.33 & 8.33 & 2.00 & 1398.80 \\
\hline & $100 p p m$ & 157.33 & 8.33 & 2.43 & 1386.20 \\
\hline & 200ppm & 178.33 & 13.33 & 2.90 & 1555.60 \\
\hline & 300ppm & 182.67 & 14.23 & 3.13 & 1492.60 \\
\hline & Mean & 170.17 & 11.06 & 2.62 & 1458.30 \\
\hline \multirow{5}{*}{$\begin{array}{l}\text { Ovear } \\
\text { all } \\
\text { means }\end{array}$} & Control & 101.87 & 5.80 & 2.05 & 989.40 \\
\hline & 100ppm & 102.87 & 5.26 & 2.36 & 1029.16 \\
\hline & 200ppm & 115.20 & 7.40 & 2.77 & 1104.67 \\
\hline & 300ppm & 123.53 & 8.33 & 3.05 & 1179.24 \\
\hline & Mean & 110.87 & 6.70 & 2.56 & 1075.62 \\
\hline \multicolumn{6}{|c|}{ L.S.D at $5 \%$ level for: } \\
\hline \multirow{2}{*}{\multicolumn{2}{|c|}{$\begin{array}{ll}\mathbf{F e}+\text { Mn nano } & (\mathbf{F}) \\
\text { Interaction } & (\mathbf{N}) \times(F)\end{array}$}} & 3.78 & 0.11 & 0.08 & 57.43 \\
\hline & & N.S. & N.S. & 0.18 & 128.43 \\
\hline
\end{tabular}


Table 3. Effect of nano metric nitrogen and micro element fertilizer on some characters of canola c.v. Serw4 on 2018/2019 season.

\begin{tabular}{|c|c|c|c|c|c|}
\hline Nitrogen & $\mathrm{Fe}+\mathrm{Mn}$ & $\begin{array}{c}\text { Plant } \\
\text { height }\end{array}$ & $\begin{array}{l}\text { Number of } \\
\text { branches }\end{array}$ & $\begin{array}{c}\text { 1000seed } \\
\text { weight }\end{array}$ & Seed yield \\
\hline \multirow{5}{*}{$\begin{array}{c}10 \mathrm{~kg} \mathrm{~N} \\
\text { mineral+ } 20 \\
\text { nano }\end{array}$} & Control & 113.00 & 4.33 & 2.03 & 931.20 \\
\hline & 100ppm & 115.00 & 4.33 & 2.23 & 1113.20 \\
\hline & 200ppm & 127.67 & 6.33 & 2.33 & 1186.00 \\
\hline & 300ppm & 134.00 & 7.33 & 2.77 & 1214.00 \\
\hline & Mean & 122.41 & 5.58 & 2.34 & 1111.10 \\
\hline \multirow{5}{*}{$\begin{array}{c}20 \mathrm{~kg} N \\
\text { mineral+ } 20 \\
\text { nano }\end{array}$} & Control & 123.67 & 5.00 & 2.03 & 1272.80 \\
\hline & 100ppm & 124.00 & 5.67 & 2.23 & 1305.00 \\
\hline & 200ppm & 134.67 & 7.33 & 2.77 & 1404.40 \\
\hline & 300ppm & 144.67 & 7.67 & 2.93 & 1421.20 \\
\hline & Mean & 131.75 & 6.41 & 2.49 & 1350.85 \\
\hline \multirow{5}{*}{$\begin{array}{c}\text { 30kg } N \\
\text { mineral+ } 20 \\
\text { nano }\end{array}$} & Control & 129.67 & 6.67 & 2.04 & 1222.40 \\
\hline & 100ppm & 132.00 & 7.00 & 2.27 & 1306.40 \\
\hline & 200ppm & 145.00 & 7.93 & 2.93 & 1412.80 \\
\hline & 300ppm & 158.67 & 9.33 & 3.03 & 1489.80 \\
\hline & Mean & 141.33 & 7.73 & 2.56 & 1357.85 \\
\hline \multirow{5}{*}{$\begin{array}{c}40 \mathrm{~kg} \mathrm{~N} \\
\text { mineral+ } 20 \\
\text { nano }\end{array}$} & Control & 133.33 & 7.00 & 2.07 & 1537.40 \\
\hline & 100ppm & 147.00 & 7.00 & 2.63 & 1393.20 \\
\hline & 200ppm & 153.67 & 8.33 & 2.93 & 1558.40 \\
\hline & 300ppm & 163.67 & 9.33 & 3.23 & 1751.60 \\
\hline & Mean & 149.41 & 7.91 & 2.71 & 1560.15 \\
\hline \multirow{5}{*}{$\begin{array}{c}50 \mathrm{~kg} \mathrm{~N} \\
\text { mineral+ } 20 \\
\text { nano }\end{array}$} & Control & 165.33 & 7.67 & 1.87 & 1456.20 \\
\hline & 100ppm & 166.00 & 8.67 & 2.50 & 1372.20 \\
\hline & 200ppm & 176.67 & 9.67 & 2.80 & 1545.80 \\
\hline & $300 \mathrm{ppm}$ & 185.00 & 12.00 & 3.17 & 1176.20 \\
\hline & Mean & 173.25 & 9.50 & 2.58 & 1387.60 \\
\hline \multirow{5}{*}{$\begin{array}{c}\text { Ovear all } \\
\text { means }\end{array}$} & Control & 137.50 & 6.33 & 2.16 & 1295.43 \\
\hline & 100ppm & 133.40 & 6.13 & 2.08 & 1284.00 \\
\hline & 200ppm & 136.80 & 6.53 & 2.37 & 1298.00 \\
\hline & 300ppm & 147.54 & 8.00 & 2.75 & 1421.48 \\
\hline & Mean & 138.81 & 6.74 & 2.34 & 1324.72 \\
\hline \multicolumn{6}{|c|}{ L.S.D at $5 \%$ level for: } \\
\hline \multicolumn{2}{|c|}{ Nitrogen fertilizer $(\mathbf{N})$} & 2.27 & 0.61 & 0.09 & 17.23 \\
\hline $\mathrm{Fe}+\mathrm{Mn}$ nano & (F) & 5.57 & N.S. & 0.23 & 42.21 \\
\hline Interaction & $(\mathbf{N}) \mathbf{x}(\mathbf{F})$ & 4.47 & N.S. & 0.12 & 18.93 \\
\hline
\end{tabular}

Data recorded in Tables (2) and (3) indicate that the interaction between nitrogen fertilizer and foliar spraying with $\mathrm{Fe}+\mathrm{Mn}$ on canola plant height was significant in 2018/2019 season. However, the highest plant height value $182.67 \mathrm{~cm}$ and $185.00 \mathrm{~cm}$ were obtained under the application of nitrogen fertilizer at concentrate $20 \mathrm{~kg} \mathrm{~N}$ nano $+50 \mathrm{~kg} \mathrm{~N}$ mineral/ fed with foliar spraying with $\mathrm{Fe}+\mathrm{Mn} 300 \mathrm{ppm}$ in 2017/ 2018 and 2018/ 2019 seasons, respectively. Wissuwa, et. al. 2008 results agreed the similar data. 


\section{2- Number of branches /plant}

Tables (2) and (3) show the influence of nitrogen fertilizer rates and spraying with nano $\mathrm{Fe}+\mathrm{Mn}$ different concentrations as well as their interaction on number of branches per canola c.v. Serw4 under drip irrigation system in 2017/ 2018 and 2018/2019 seasons.

Obtained results indicate that nitrogen fertilizer concentrates significantly affected number of branches in both seasons. However, 20 $\mathrm{kg} \mathrm{N}$ nano $+50 \mathrm{~N}$ mineral/ fed concentrate gave the highest number of branches as compared with $10,20,30$ and $40 \mathrm{~kg} \mathrm{~N}$ mineral $+20 \mathrm{~kg} \mathrm{~N}$ nano/ fed concentrates in both seasons. That concentrate increased the number of branches by $38.25 \%, 43.49 \%, 11.12 \%$ and $6.33 \%$ over those of $10,20,30$ and $40 \mathrm{~kg} \mathrm{~N}$ mineral $+20 \mathrm{~kg} \mathrm{~N}$ nano/ fed concentrates, respectively. Results in 2018/ 2019 season followed similar trend. These results are in agreement with those of Rathnayaka, et. al. (2018).

The results recorded in Tables (2) and (3) showed that the highest number of branches/plant was achieved from plants received nano $\mathrm{Fe}+$ $\mathrm{Mn}$ at the concentrate of $300 \mathrm{ppm}$ as a foliar application as compared with all other foliar Fe + Mn spraying concentrates in both 2017/ 2018 and 2018/ 2019 seasons. For example, in 2017/ 2018 season, Fe + Mn at concentrate $300 \mathrm{ppm}$ increased the number of branches by $30.37 \%$, $36.86 \%$ and $11.17 \%$ over those of control plants, Fe + Mn 100 ppm and $\mathrm{Fe}+\mathrm{Mn} 200 \mathrm{ppm}$ concentrations, respectively. Mirzapour and Khoshgoftar (2006) found similar results.

The statistical analysis revealed insignificant effect of the interaction between of nitrogen fertilizer rates and spraying with $\mathrm{Fe}+\mathrm{Mn}$ concentrations on number of branches in both 2017/ 2018 and 2018/ 2019 seasons as shown in Tables (2) and (3). However, the highest number of branches (14.23 and 12.00) was recorded at the application of nitrogen fertilizer rate $(20 \mathrm{~kg} \mathrm{~N}$ mineral $+50 \mathrm{~kg} \mathrm{~N}$ nano/ fed $)$ and spraying with $\mathrm{Fe}+\mathrm{Mn}$ at concentrate of 300 ppm concentrate, in 2017/ 2018 and 2018/ 2019 seasons, respectively. Sarkar, et. al. 2007 agreed that results.

\section{3- 1000-seed weight (g)}

The 1000- seed weight of canola c.v. Serw4 as affected by nitrogen fertilizer, nano metric fertilizers $\mathrm{Fe}+\mathrm{Mn}$ and their interaction under drip irrigation system in 2017/2018 and 201812019 seasons are presented in Tables (2) and (3).

Tables (2) and (3) indicate that 1000- seed weight was affected by nitrogen fertilizer rates, nano metric fertilizers $\mathrm{Fe}+\mathrm{Mn}$ in both seasons. Concerning nitrogen fertilizer, the results show that $40 \mathrm{~kg} \mathrm{~N}$ (mineral) + 20 (nano)/ fed concentrate gave the heaviest 1000- seed weight as compared with those of $10,20,30$ and $50 \mathrm{~kg} \mathrm{~N}$ (mineral $+20 \mathrm{~kg}$ nano/ fed in both seasons. This concentrate gave 19.15\%, 13.48\%, $5.67 \%$ and 
$7.63 \%$ increase in 1000- seed weight over those of 10, 20, 30 and $50 \mathrm{~kg}$ $\mathrm{N}$ (mineral $+20 \mathrm{~kg}$ nano/ fed. concentrates, respectively, in 2017/ 2018 season. The respective values in $2018 \backslash 2019$ season were $8.56 \%, 3.89 \%$, 0.78 and $3.89 \%$. This explanation is are in agreement with those of Bahrani and Pourreza 2014 and Rathnayaka, et. al. (2018).

The obtained results (Tables 2 and 3 ) showed that spraying nano metric fertilizers Fe + Mn significantly affected 1000-seed weight of canola c.v. Serw4 in both seasons. However, the highest 1000-seed weight was achieved at spraying nano metric fertilizers $\mathrm{Fe}+\mathrm{Mn}$ at the concentrate of $300 \mathrm{ppm}$ in both seasons. In 2018/ 2019 season, this concentrate (spraying nano metric fertilizers $\mathrm{Fe}+\mathrm{Mn}$ at concentrate of $300 \mathrm{ppm}$ ) gave $21.46 \%, 24.36 \%$ and $13.82 \%$ increase in 1000 -seed weight over those of control, nano metric fertilizers $\mathrm{Fe}+\mathrm{Mn}$ at the 100 and $200 \mathrm{ppm}$ concentrates, respectively. The same trend was true in 2017/ 2018 season. These findings are in agreement with those of Bakhtiari, et. al. (2015) who reported that foliar application of $\mathrm{Fe}$ and manganese compounds with the technology of Nano may be a solution to the problem.

Data recorded in Tables (2) and (3) indicate that the interaction between nitrogen fertilizer rates and nano metric fertilizers $\mathrm{Fe}+\mathrm{Mn}$ at concentrate of $300 \mathrm{ppm}$ foliar application had significant effect on 1000seed weight in both the experimental seasons. However, in 2017/ 2018 season, the heaviest 1000 -seed weight $(3.37 \mathrm{~g})$ was achieved from applying nitrogen fertilizer rate $40 \mathrm{~kg}$ mineral+ $20 \mathrm{~kg}$ nano and applying of nano metric fertilizers $\mathrm{Fe}+\mathrm{Mn}$ at concentrate of $300 \mathrm{ppm}$. Results in 2018/ 2019 followed similar trend. That result were in agreement with Zayed, et. al. 2011.

\section{4- Seed yield (kg/ fed)}

Seed yield of canola c.v. Serw4as affected by nitrogen fertilizer rates and foliar spraying with $\mathrm{Fe}+\mathrm{Mn}$ under drip irrigation system in 2017/ 2018 and 2018/ 2019 seasons, is shown in Tables (2) and (3).

Results presented in Tables (2) and (3) show that nitrogen fertilizer rates significantly affected the seed yield per feddan of canola c.v. Serw4 in both seasons. However, the nitrogen fertilizer rates $(20 \mathrm{~kg}$ $\mathrm{N}$ nano $+40 \mathrm{~kg}$ mineral/ fed) concentrate gave the highest seed yield per feddan as compared with the all other concentrates in both seasons. This concentrate gave $30.06 \%, 13.74 \%, 14.01 \%$ and $7.22 \%$ increase in seed yield over those of $10,20,30$ and $50 \mathrm{~kg} \mathrm{~N}$ mineral $+20 \mathrm{~kg} \mathrm{~N}$ nano/ fed concentrates, respectively in 2017/ 2018season. Results in 2018\} 2 0 1 9 season followed similar trend. These results are in agreement with those of Rathnayaka, et. al. (2018).

Data recorded in Tables (2) and (3) show that spraying canola c.v. Serw4 with $\mathrm{Fe}+\mathrm{Mn}$ concentrations under drip irrigation system 
significantly affected seed yield per feddan in both seasons. However, the highest seed yield per feddan was obtained under applying $\mathrm{Fe}+\mathrm{Mn}$ at concentrate $300 \mathrm{pm}$ in both seasons. This concentrate gave $16.10 \%$, $12.73 \%$ and $6.32 \%$ increase in seed yield over those of control, spraying canola plants with $\mathrm{Fe}+\mathrm{Mm} 100$ and 200ppm concentrates, respectively in 2017/ 2018 season. The respective values in 2018/2019 season were $8.87 \%, 9.67 \%$ and $8.69 \%$. The highest seed yield under this concentrate, i. e, $\mathrm{Fe}+\mathrm{Mn} 300 \mathrm{ppm}$ might be attributed to that its significant increasing in 1000-seed weight as shown in Tables (2) and (3). Similar results have also been reported by Wissuwa, et. al., (2008).

Data presented in Tables (2) and (3) show that interaction effects between the nitrogen fertilizer levels, and foliar application of $\mathrm{Fe}+\mathrm{Mn}$ concentrations on seed yield was significant in 2017/ 2018 and 2018/ 2019 seasons, the highest seed yield $(1755.80 \mathrm{~kg} / \mathrm{fed})$ and $(1751.60 \mathrm{~kg} /$ fed) in 2017/ 2018 and 2018/2019 seasons, was obtained respectively at application of nitrogen fertilizer with concentrate $20 \mathrm{~kg}$ nano $+40 \mathrm{~kg} \mathrm{~N}$ mineral as soil amendment with the foliar application with $\mathrm{Fe}+\mathrm{Mn}$ concentration of 300ppm in both seasons. Sarkar, et. al. (2007) and Wissuwa, et. al. (2008) come to the same results.

\section{5- Oil content $\%$ in seeds}

The oil content \% of seed canola c.v. Serw4 as affected by nitrogen fertilizer, nano metric fertilizers $\mathrm{Fe}+\mathrm{Mn}$ and their interaction under drip irrigation system in 2017/2018 and 201812019 seasons are presented in Table (4).

Table (4) indicate that oil content \% was significant affected by nitrogen fertilizer rates, nano metric fertilizers $\mathrm{Fe}+\mathrm{Mn}$ in both seasons. Concerning nitrogen fertilizer, the results show that $40 \mathrm{~kg} \mathrm{~N}$ (mineral) + 20 (nano)/ fed concentrate had the heaviest oil content \% as compared with those of $10,20,30$ and $50 \mathrm{~kg} \mathrm{~N}$ (mineral $+20 \mathrm{~kg} \mathrm{nano} / \mathrm{fed}$ in both seasons. This concentrate gave $9.08 \%, 3.35 \%, 8.31 \%$ and $10.64 \%$ increase in oil content $\%$ over those of 10,20,30 and $50 \mathrm{~kg} \mathrm{~N}$ (mineral + $20 \mathrm{~kg}$ nano/ fed. concentrate, respectively, in 2017/ 2018 season. The respective values in $2018 \backslash 2019$ season were $8.56 \%, 3.89 \%, 0.78$ and $3.89 \%$. This explanation is are in agreement with those of Muhammad, et al., (2007).

The obtained results (Table 4) showed that spraying nano metric fertilizers $\mathrm{Fe}+\mathrm{Mn}$ significantly affected oil content $\%$ of seed canola c.v. Serw4 in both seasons. However, the highest oil content \% was achieved at spraying nano metric fertilizers $\mathrm{Fe}+\mathrm{Mn}$ at concentrate 300 ppm in both seasons. In 2017/ 2018 season, this concentrate (spraying nano metric fertilizers $\mathrm{Fe}+\mathrm{Mn}$ at concentrate $300 \mathrm{ppm}$ ) gave $8.87 \%$, $13.56 \%$ and $8.73 \%$ increase in oil content $\%$ over those of control, nano metric fertilizers $\mathrm{Fe}+\mathrm{Mn}$ at concentrate 100 and 200 ppm concentrates, 
respectively. The same trend was true in 2018/ 2019 season. These findings are in agreement with those of Sarkar, et. al. 2007, Wissuwa, et. al. 2008 shown that a small amount of nutrients, especially $\mathrm{Fe}$, and Mn that have been applied by foliar spraying have significantly increased crop yields.

Table 4. Effect of nano metric nitrogen rates and micro element fertilizer on Oil content inseeds and Oil yield of canola c.v. Serw4 on 2017/2018 and 2018/2019 seasons.

\begin{tabular}{|c|c|c|c|c|c|}
\hline \multirow[t]{2}{*}{ Nitrogen } & \multirow[t]{2}{*}{$\mathrm{Fe}+\mathrm{Mn}$} & $\begin{array}{c}\text { Oil content } \\
\%\end{array}$ & $\begin{array}{c}\text { Oil content } \\
\%\end{array}$ & Oil yield & Oil yield \\
\hline & & $2017 / 2018$ & $2018 / 2019$ & $2017 / 2018$ & $2018 / 2019$ \\
\hline \multirow{5}{*}{$\begin{array}{c}10 \mathrm{~kg} N \\
\text { mineral+ } 20 \\
\text { nano }\end{array}$} & Control & 29.03 & 32.66 & 257.73 & 304.13 \\
\hline & 100ppm & 28.20 & 31.80 & 313.92 & 354.00 \\
\hline & 200ppm & 31.43 & 32.40 & 365.72 & 384.26 \\
\hline & 300ppm & 35.15 & 35.73 & 433.12 & 433.76 \\
\hline & Mean & 30.95 & 33.15 & 342.62 & 369.03 \\
\hline \multirow{5}{*}{$\begin{array}{c}20 \mathrm{~kg} N \\
\text { mineral+ } 20 \\
\text { nano }\end{array}$} & Control & 33.65 & 33.10 & 421.23 & 421.30 \\
\hline & 100ppm & 31.81 & 30.17 & 424.03 & 393.72 \\
\hline & 200ppm & 32.01 & 37.37 & 448.65 & 524.82 \\
\hline & 300ppm & 34.14 & 38.21 & 490.46 & 543.04 \\
\hline & Mean & 32.90 & 34.71 & 446.09 & 470.72 \\
\hline \multirow{5}{*}{$\begin{array}{c}30 \mathrm{~kg} N \\
\text { mineral+ } 20 \\
\text { nano }\end{array}$} & Control & 31.79 & 36.10 & 406.40 & 441.29 \\
\hline & 100ppm & 29.00 & 33.21 & 363.83 & 433.86 \\
\hline & 200ppm & 29.97 & 34.27 & 420.06 & 484.17 \\
\hline & 300ppm & 34.06 & 37.42 & 501.23 & 557.48 \\
\hline & Mean & 31.21 & 35.25 & 422.88 & 479.20 \\
\hline \multirow{5}{*}{$\begin{array}{c}40 \mathrm{~kg} \mathrm{~N} \\
\text { mineral+ } 20 \\
\text { nano }\end{array}$} & Control & 32.10 & 38.43 & 490.81 & 590.82 \\
\hline & 100ppm & 31.45 & 35.47 & 454.45 & 494.17 \\
\hline & 200ppm & 34.25 & 34.38 & $\begin{array}{l}533.27 \\
\end{array}$ & 535.78 \\
\hline & 300ppm & 38.36 & 39.82 & 673.52 & 697.49 \\
\hline & Mean & 34.04 & 37.03 & 538.01 & 579.56 \\
\hline \multirow{5}{*}{$\begin{array}{c}50 \mathrm{~kg} \mathrm{~N} \\
\text { mineral+ } 20 \\
\text { nano }\end{array}$} & Control & 31.08 & 36.27 & 434.75 & 528.16 \\
\hline & 100ppm & 29.09 & 36.06 & 403.25 & 494.82 \\
\hline & 200ppm & 30.22 & 37.10 & 470.10 & 573.49 \\
\hline & 300ppm & 31.29 & 38.07 & 467.03 & 447.78 \\
\hline & Mean & 30.42 & 36.88 & 443.78 & 511.06 \\
\hline \multirow{5}{*}{$\begin{array}{c}\text { Ovear all } \\
\text { means }\end{array}$} & Control & 31.53 & 35.31 & 311.96 & 457.42 \\
\hline & 100ppm & 29.91 & 33.34 & 307.82 & 428.09 \\
\hline & 200ppm & 31.58 & 35.10 & 348.85 & 455.60 \\
\hline & 300ppm & 34.60 & 37.85 & 408.02 & 538.03 \\
\hline & Mean & 31.90 & 35.40 & 344.16 & 469.78 \\
\hline \multicolumn{6}{|c|}{ L.S.D at $5 \%$ level for: } \\
\hline \multicolumn{2}{|c|}{ Nitrogen fertilizer $(\mathbf{N})$} & 2.95 & 2.85 & 28.57 & 27.60 \\
\hline $\mathbf{F e}+$ Mn nano & (F) & 1.63 & 1.62 & 16.61 & 16.44 \\
\hline Interaction & $(\mathbf{N}) \mathbf{x}(\mathbf{F})$ & N.S. & N.S. & N.S. & N.S. \\
\hline
\end{tabular}
between of nitrogen fertilizer rates and spraying with $\mathrm{Fe}+\mathrm{Mn}$ concentrations on number of branches in both 2017/ 2018 and 2018/ 2019 
seasons as shown in Table (4). However, the highest oil content \% inseeds (38.36\% and 39.82) was recorded at the application of nitrogen fertilizer rate $(20 \mathrm{~kg} \mathrm{~N}$ mineral $+40 \mathrm{~kg} \mathrm{~N}$ nano/ fed) and spraying with $\mathrm{Fe}+\mathrm{Mn}$ at concentrate 300 ppm concentrate, in 2017/ 2018 and 2018/ 2019 seasons, respectively.

\section{6- Oil yield (kg) /fed}

Oil yield of canola c.v. Serw4as affected by nitrogen fertilizer rates and foliar spraying with $\mathrm{Fe}+\mathrm{Mn}$ under drip irrigation system in 2017/ 2018 and 2018/ 2019 seasons, is shown in Table (4).

Results presented in Table (4) show that nitrogen fertilizer rates significantly affected the oil yield per feddan of canola c.v. Serw4 in both seasons. However, the nitrogen fertilizer rate $(20 \mathrm{~kg} \mathrm{~N}$ nano $+40 \mathrm{~kg}$ mineral/ fed) concentrate gave the highest oil yield per feddan as compared with the all other concentrates in both seasons. This concentrate gave $36.41 \%$, $16.63 \%, 21.16 \%$ and $17.08 \%$ increase in oil yield over those of 10, 20, 30 and $50 \mathrm{~kg} \mathrm{~N}$ mineral $+20 \mathrm{~kg} \mathrm{~N}$ nano/ fed concentrates, respectively in 2017/ 2018 season. Results in 2018\} 2 0 1 9 \text { season followed similar trend. These } results are in agreement with those of Muhammad, et al., (2007).

Data recorded in Table (4) show that spraying canola c.v. Serw4 with $\mathrm{Fe}$ + Mn applied under drip irrigation system significantly affected oil yield per feddan in both seasons. However, the highest oil yield per feddan was obtained at applying $\mathrm{Fe}+\mathrm{Mn}$ at concentrate $300 \mathrm{pm}$ concentrate in both seasons. This concentrate gave $23.54 \%, 24.56 \%$ and $14.50 \%$ increase in seed yield over those of control, spraying canola plants with $\mathrm{Fe}+\mathrm{Mm} 100$ and 200ppm concentrates, respectively in 2017/ 2018 season. The respective values in 2018/ 2019 season were $14.98 \%, 20.43 \%$ and $15.32 \%$. The highest oil yield under this concentrate, i. e, $\mathrm{Fe}+\mathrm{Mn} 300 \mathrm{ppm}$ might be attributed to that its significant increasing in oil content $\%$ and seed yield as shown in Tables 2, 3 and 4. Similar results have also been reported by Sarkar, et. al. 2007.

The statistical analysis revealed insignificant effect of the interaction between nitrogen fertilizer rates and spraying with $\mathrm{Fe}+\mathrm{Mn}$ on oil yield in both 2017/ 2018 and 2018/ 2019 seasons as shown in Table (4). However, the highest.

Nitrogen $(\mathrm{N})$ management in canola growing is a key factor of achieving high yield and oil level. In crop rotation, canola growth following cereal crops, so the soil needs a balanced $\mathrm{N}$ fertilization. canola is not suitable crop to grow in monoculture cropping systems. Balanced nutrient budget in soil for canola production is a very important for $\mathrm{N}$ fertilization program. Therefore, the total $\mathrm{N}$ rate can be assessed based on the yield potential of canola variety and estimated soil nutrient supply during canola growing season in soil. Nitrogen requirement of canola plant can be estimated from the expected potential yield. Using high levels of $\mathrm{N}$ fertilization can increase seed protein rate and cause to reduce the oil content. However, oil content of canola crop may decrease for getting high seed 
yield from per ha. Using large amount of $\mathrm{N}$ fertilizer during canola growing season can decrease the oil content of the harvested crop. Unbalanced nitrogen fertilization in canola growing season may change harvested seed fatty acid profile and glucosinolate contents (Süzer 2010). According to the limitations of soil usage of micro-nutrients (such as consolidation and residual effects) foliar spraying or leaf feeding is one of the effective ways in resolve plants food requirement to micronutrients (Wang et al., 2004). High phosphorus in the soil, high $\mathrm{pH}$, high lime, high soil moisture, cold temperatures and large amounts of $\mathrm{HCO} 3$ in root environment are the causes of $\mathrm{Fe}$ and Mn deficiency in the soil (Sun et al., 2007). If adequate and absorbable amounts of Fe are not available for the plant chlorophyll production in leaf decreases and the leaves become pale. It should be noted that not only Fe deficiency results in yellowish leaf, but also in some cases deficiency of nitrogen and some other nutrients, some pests and diseases and low light lead to pale leaf (Singh, 2001). Nano fertilizers are the most important function of nanotechnology in the production phase of agriculture.

Application of nano fertilizers instead of common fertilizers, nutrients are provided to plants gradually and in a controlled manner. The nanotechnology increases the application efficiency of fertilizers, reduces soil pollution and environmental risks of chemical fertilizers (Naderi $\boldsymbol{e t}$ al., 2011). Nano materials are much smaller and lighter; they interact better in the environment and may be a solution for the problem of iron nutrition in saline and lime soils. Iron and manganese Nano oxide is smaller than the common iron and manganese oxides and forms more complexes and makes the Fe and Mn more available to plants (Mazaherinia et al., 2010). Fe and manganese deficiency is a widespread nutritional problem in plants growing mainly in high $\mathrm{pH}$ and calcareous soils. Foliar application of $\mathrm{Fe}$ and manganese compounds with the technology of Nano may be a solution to the problem (Bakhtiari et al., 2015).

\section{CONCLUSIONS}

Nitrogen, iron and manganese uptake are controlled by the two major factors, availability of these elements in the soil and the ability of plants to acquire them. Application methods of $\mathrm{N}$ and micronutrients are very important to attain the best absorption. Sometimes response of the plants is different to application methods of fertilizers, for example in calcareous soil Fe and Mn are not available for plants, in this times, foliar application is a useful method for nourish of the plants. The results of this study demonstrated that, $\mathrm{N}, \mathrm{Fe}$ and $\mathrm{Mn}$ used as a nanometric fertilizers had positive effect on yield and quality of canola oil. In addition to this, we also recommend that plants treated with $40 \mathrm{~kg} \mathrm{~N}$ $+20 \%$ nano. N/ fed and sprayed with Fe $+\mathrm{Mn}$ at concentrations $300 \mathrm{ppm}$ gave the best quality and quantity in canola production. 


\section{REFERENCES}

Alberta Agriculture. (1984). Irrigation Canola Production. Agdex No. 149/561-1. Alberta Agriculture, Edmonton, Alberta

Al-Solaimani, S.G. ; F. Alghabari and M. Z. Ihsan (2015). Effect of different rates of nitrogen fertilizer on growth, seed yield, yield components and quality of canola (Brassica napus L.) under arid environment of Saudi Arabia. International Journal of Agronomy and Agricultural Research, 6(4): 268-274.

A.O.A.C. (1980).Association of Official Agricultural Chemists. Official Methods of Analysis. Washington 11 th E d.D.C.pp 882.

Arnold, K. (1986). Methods of soil analysis, physical methods. Second America, Inc. madison Wisconsin.

Bahrani, A. and J. Pourreza (2014). Effects of micronutrients on seed yield and oil content of Brassica napus L. Cv. Talayeh. Bangladesh J. Bot., 43(2): 231-233

Bakhtiari, M. ; P. Moaveni and B. Sani (2015). The effect of iron nanoparticles spraying time and concentration on wheat. Biological Forum An International Journal, 7: 679-683.

Commodity Research Bureau. (2005). CRB commodity year book. Commodity Research Bureau, Jersey City, NJ.

Davarpanah, S. ; A. Tehranifar ; G. Davarynejad ; M. Aran ; J. Abadía and R. Khorassani (2017). Effects of foliar nanonitrogen and urea fertilizers on the physical and chemical properties of pomegranate (Punica granatum cv. Ardestani) fruits. Hort. Science, 52(2): 288-294.

FAOSTAT. (2014). Data, (2013). Food and Agricultural commodities production, Rome, Italy. Available online at: http://faostat.fao.org [Accessed 01 March 2015].

Hopkins, W.G. and N.P.A. Hunter (2004). Introduction to Plant Physiology. 3rd Edn, John Wiley and Sons Inc., New York, ISBN: 978-0-471- 38915-6, 576 P.

Khaliq, A. ; A. Matloob ; M.Z. Ihsan ; R.N. Abbas ; Z. Aslam and F. Rasool (2013). Supplementing herbicides with manual weeding improves weed control efficiency, growth and yield of direct seeded rice. International Journal of Agriculture and Biology, 15(2): 191-199.

Kumar, S.; J. Sing and K.K. Dhingra (1997). Leaf area index relationship with solar-radiation interception and yield of Indian mustard (Brassica juncea) as influenced by plant population and nitrogen, Indian Journal of Agronomy, 42: 348-351.

Mirzapour, M.H. and A.H. Khoshgoftar (2006). Zinc application effects on yield and seed oil content of sunflower grown on a saline calcareous soil. J. Plant Nutr., 29:1719-1727. 
Muhammad, N.; M.A. Cheema ; M.A. Wahid ; N. Ahmad and M. Zaman (2007). Effect of source and method of nitrogen fertilizer application on seed yield and quality of canola (Brassica napus L.), Pakistan Journal of Agriculture Science, 44: 74-78.

Naderi, M. ; A.A. Danesh-Shahraki and R. Naderi (2011). Application of nanotechnology in the optimization of formulation of chemical fertilizers. Iranian Journal of Nanotechnology, 12: 16-23.

Page, A.L. ; R.H. Miller and D.R. Keeney (1982).Methods of Soil Analysis. Part 2 Chemical and Microbiological Properties. American Society of Agronomy, No. 9. Madison, Wisconsin, USA

Qaderi, M.M.; L.V. Kurepin and D.M. Reid (2012). Effects of temperature and watering regime on growth, gas exchange and abscisic acid content of canola (Brassica napus) seedlings. Environmental and Experimental Botany, 75: 107-113.

Rathnayaka, R.M.N.N. ; Y.B. Iqbal and L.M. Rifnas (2018). Influence of urea and nano-nitrogen fertilizers on the growth and yield of rice (Oryza sativa L.) cultivar 'Bg 250'. Influence of Urea and Nano-Nitrogen Fertilizers on the Growth and Yield of Rice (Oryza sativa L.) Cultivar 'Bg 250', 5(2): 7-7.

Sarkar, D. ; B. Mandal and M. C. Kundu (2007). Increasing use efficiency of boron fertilizer's by rescheduling the time and methods of application for crops in India. Plant and Soil, 301(12): 77-85.

Steel, R.G. ; J.H. Torrie and D.A. Dickey (1997). Principals and Procedures of Statistics. A biometrical approach. 3rd Eds. McGraw-Hill, Inc. Book Co., New York, U. S. A., PP: 352-358

Sultana, N. ; T. Ikeda and M. A. Kashem (2001). Effect of foliar spray of nutrient solutions on photosynthesis, dry matter accumulation and yield in seawater-stressed rice. Environ. Exp. Bot., 46:129-140.

Süzer, S. (2010). Effects of Potassium Fertilization on Sunflower (Helianthus annuus L.) and Canola (Brassica napus ssp. oleifera L.) Growth. Proceedings of the Regional Workshop of the International Potash Institute, 22-25 November, Antalya, Turkey.

Wissuwa, M. ; A. M. Ismail and R. D. Graham (2008). Rice seed zinc concentrations as affected by genotype native soil-zinc availability, and zinc fertilization. Plant Soil., 306:37-48.

Zayed, B.A.; A.K.M. Salem and H.M. Sharkawy (2011). Effect of different micronutrient concentrates on rice (Oryza sativa L.) growth and yield under saline soil conditions. World J. Agric. Sci., 7: 179-184. 
Egypt. J. of Appl. Sci, 36 (3) 2021

تأثير السماد النانوي بالنيتروجين والعناصر الصغرى على

المحصول ومكوناته في الكانولا

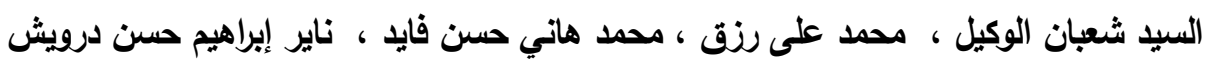

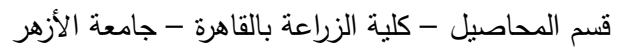

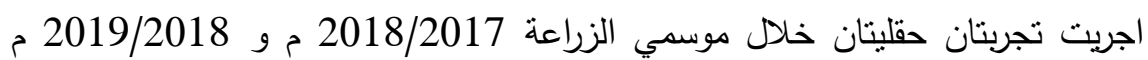

في جمعية الحسين لاستصلاح وزراعة الأراضي - الكيلو 64 طريق التئ القاهرة الإنكندرية

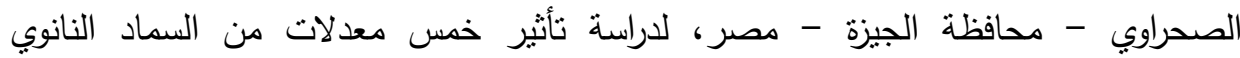

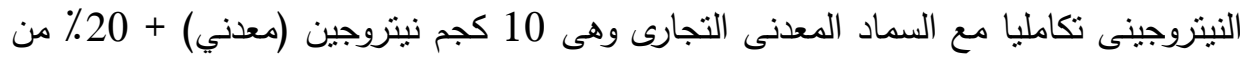

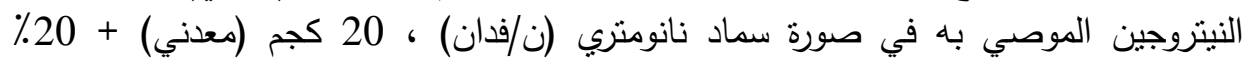

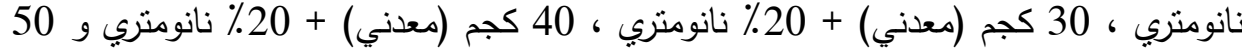

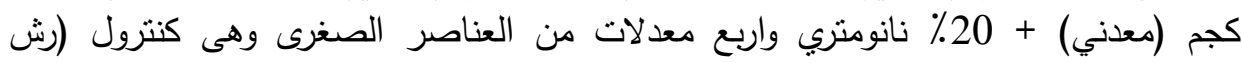

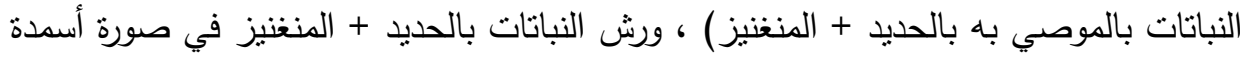

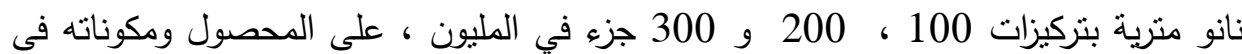

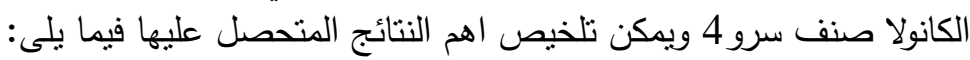

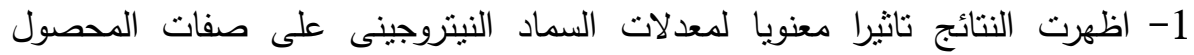

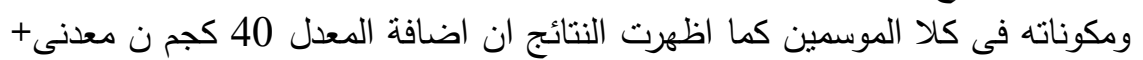

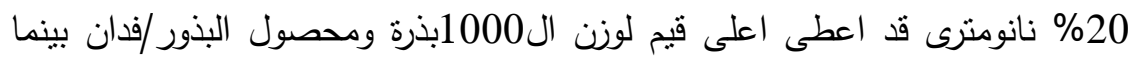

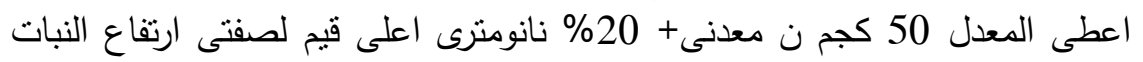
وعدد الافرع /النبات فى كلا الموسمين

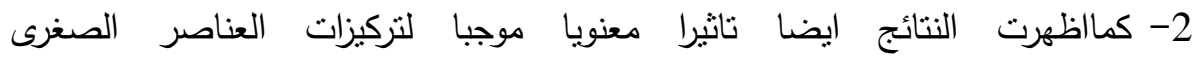

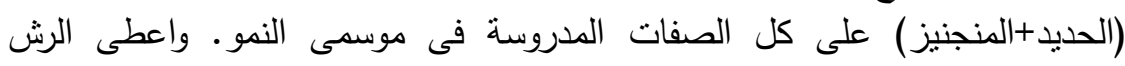

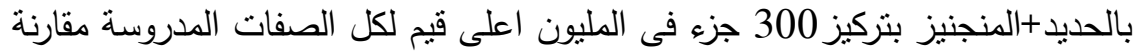

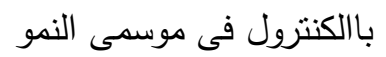
3- كان للتفاعل بين معدلات السماد النيتروجينى (المعدنى+ النانومترى) وتركيزات

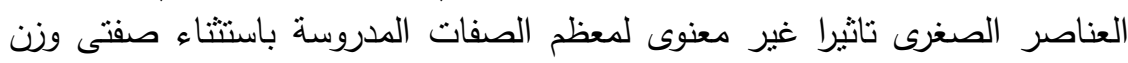

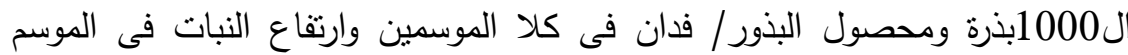

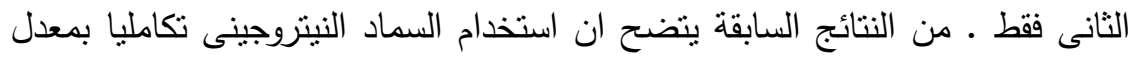

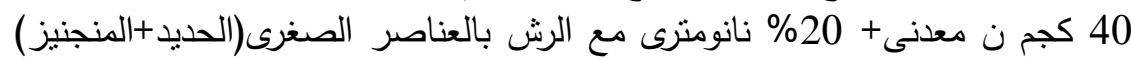

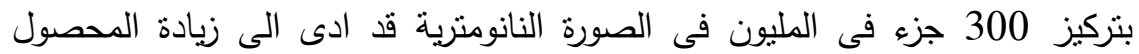

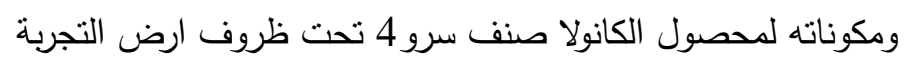

